\title{
The Role of Sharia National Financial Committee in the Development of Sharia Banking Law in Indonesia
}

\author{
M. Chairul Ismail ${ }^{1}$ Ro'fah Setyowati ${ }^{*}$, Muhyidin ${ }^{1}$

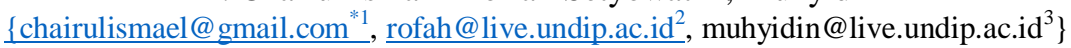

Fakultas Hukum, Universitas Diponegoro, Jl. Prof. H. Soedarto, S.H., Semarang, Indonesia $50275^{1}$

\begin{abstract}
The National Sharia Finance Committee is an embodiment of one of the recommendations listed in the Indonesian Sharia Finance Architecture Masterplan. The purpose of this study is to determine how the role of the National Committee of Islamic Finance in the development of Islamic banking law in Indonesia. This study uses a juridical-normative approach, with descriptive research specifications. The method of data collection is carried out by examining secondary data obtained through library studies. Based on the results of the study, it was concluded that the National Sharia Finance Committee acts as an independent supervisory body that monitors the implementation of the Road Map for the development of Islamic banking and ensures that all stakeholders meet the requirements of the master plan.
\end{abstract}

Keywords: Masterplan, Sharia Banking, National Sharia Finance Committee, Role

\section{Introduction}

\subsection{Background}

In this modern era, the existence of banking financial institutions is very much needed in the economic world. Its function as a fund collector is very instrumental in supporting the economic growth of a nation. [1] The fund is then distributed to those in needs. [2] However, the conventional banking system, which is an implementation of the capitalist system that has been applied for a long time causes an economic inequality happening today. It is an evidence of failure in creating justice and economic equality. [3] Therefore, it is necessary to develop an alternative system that emphasizes sharing mechanism as a tool to drive the economy, namely the sharia system. [1]

The Islamic banking system is different from the conventional banking system, because the Islamic financial and banking system is a subsystem of an Islamic economic system whose scope is wider. Islamic economic law, methodologically, is a product of human thought (the concept of insaniyah), but in a substantial spirit is a divine because it was introduced from the concept of the concept of the Koran, which is nothing but the revelation of God. [4] In carrying out its business, Islamic banking is demanded not only to focus on commercial goals that are reflected in the achievement of profits, but also its role in providing broad welfare for Muslim and non-Muslim community. This causes a very perfect relationship between Islamic economics and Islam.

The passing of Law Number 21 of 2008 concerning Sharia Banking is a breath of fresh air for the Islamic banking industry. [5] With this ratification, the sharia banking industry in 
Indonesia is expected to develop more rapidly and provide greater benefits. Legal certainty and security guarantees will also be more evident for investors and Islamic banking businesses. After the promulgation of the Act the development of Islamic banking is increasingly rapid, the growth of total assets of Islamic banking on average per year is above $33 \%$ in the last five years. Until October 2010, the total assets of sharia banking reached 86 trillion rupiah. [4] It is known that in 2010, the number of Sharia Commercial Banks (BUS) experienced an increase. The increase in the number of BUS is due to the number of Sharia Business Units (UUS) owned by Conventional Commercial Banks (BUK) that have conducted spin-offs to form new BUSs. [6] In addition to seeing the potential of the sharia banking market which is still very large, what makes the UUS trend to Spin-offs and form a new BUS is also accompanied by the basis of wanting to advance sharia banking more efficiently, flexibly and independently in determining their own management policies. [7] The number of BUS is expected to accelerate the development of the Islamic banking industry in Indonesia, because BUS management is more focused when compared to UUS. [8]

Until 2010, according to Ro'fah Setyowati, the sharia banking sector is the most prominent Islamic financial institution compared to other institutions when viewed from various aspects. [9] However, until this time, it is not yet able to reach the majority of Indonesian people due to the lack of Islamic banking assets. Until August 2019, there were 14 Sharia Commercial Banks in Indonesia, 320.882 billion Rupiah total assets, 1,896 offices (478 branch offices, 1,223 sub-branch offices, 197 cash offices), 2,779 ATMs, and 49,873 people. The total assets of Sharia Business Units in Indonesia are 162,218 billion Rupiah, the number of conventional commercial banks that have UUS 20, the number of UUS 375 offices, 158 branch offices, 157 sub-branch offices, 60 cash offices, ATM 166, total workforce of 5,055 people. While the Sharia People's Financing Bank in Indonesia there are 165, the number of offices is 536 units, the number of workers is 5,291 people (in July 2019). [10]

When compared to Malaysia, Indonesia market share is less. That happens because government intervention takes large portion in developing it. In addition, it also first started developing Islamic banking. According to M. Shabri Abd Majid, the difference is in the political support (political will) between Malaysia and Indonesia to develop the sharia banking, and therefore is influenced the growth of the sharia banking industry in both countries. [11] Strong political support in Malaysia has encouraged the rapid development of this institution, for example with careful preparation in giving birth to Islamic banks both in terms of regulation and management. [10] It is known that in terms of the number of Islamic banks operating in Indonesia have more numbers, but its role is not as maximal as in Malaysia. That is because in terms of the size of capital owned by Islamic banks in Indonesia has a relatively small size. Therefore, the government plans to consolidate state-owned Islamic banks to be able to have large capacity for Islamic banks so that they can be more competitive in the global Islamic banking industry. The plan for consolidation is based on capital problems owned by Islamic banks in Indonesia, which are still not large enough to compete at the global level. Not only Indonesia, problems related to Islamic banking capital are also experienced by other countries such as Bahrain. [12] The same step is taken to urge banks to consolidate and form larger and stronger institutions in Bahrain. In recent years, the Bahrain banking sector has carried out several mergers so that it has positively changed the financial structure of Islamic banking in the country. Malaysia, which already has a large capacity Islamic bank, also does this. [13]

Consolidation planned by the government to form a large Islamic bank owned by SOEs has not yet been carried out. This is due to the absence of an appropriate consolidation mechanism scheme to consolidate BUMN-owned BUS, and the absence of alignment of 
policies determined by each BUS. Therefore, through Government Regulation No. 91 of 2016, the National Sharia Finance Commission (KNKS) was formed, one of which aims to make Indonesia the center of Islamic finance in the regional and international regions.[12] This committee will be a solution related to the problem of lack of national vision, coordination and leadership in the development of national Islamic finance. [12]

Based on the explanation above, it is important to know how the role of the National Committee of Islamic Finance in the development of Islamic banking law in Indonesia. Therefore, the authors conducted a study with the title, "The Role of Sharia National Financial Committee in the Development of Sharia Banking Law in Indonesia."

\subsection{Formulation of the problem}

What is the role of the National Sharia Finance Committee in the development of sharia banking law in Indonesia?

\subsection{Research purposes}

To know the role of the National Sharia Finance Committee in the development of sharia banking law in Indonesia.

\section{Method}

The research method can be interpreted as a science to express and explain natural phenomena or social phenomena in human life in a systematic, orderly and scientifically responsible way. [14] According to Soerjono Soekanto research is a tool used by humans to strengthen, foster and develop knowledge. [15] Research generally aims to find, develop or test the truth of a knowledge. Finding means trying to get something to fill in the blanks or shortcomings. Developing means expanding and digging deeper into something that already exists. Testing the truth is done if what is already there is still in doubt. [16]

The research approach is the method or method used to conduct research. [17] The research method used by the author in conducting research is empirical juridical legal research. An empirical juridical approach is legal research on the enforcement or implementation of normative legal provisions in action on any particular legal event that occurs in society. [18] In other words, a research conducted on the actual situation or real situation that occurs in the community with the intention to find out and find the facts and data needed. After the data needed is collected, then it leads to the identification of problems that ultimately lead to problem solving.[19] In this study, the facts were obtained through interviews from Widiyono as an Analyst in the Financial Services Authority and Documentation Sub Division of the Regional Office 3 of Central Java and Yogyakarta Special Region.

In writing this law, qualitative legal research is used. The qualitative legal research method is a research that uses descriptive analytical data, which is what respondents will say in writing or verbally. After that, the real behavior studied will be studied as an integral part. Data obtained through field research and library research are collected and analyzed systematically to achieve clarity of the problem to be discussed. So, from the clarity of the 
problem discussed above, a conclusion can be drawn which is the answer to the problem of this research.

\section{Results and Discussion}

\subsection{Development of Islamic Banking in Indonesia}

Islamic banking as an important element in banking law in Indonesia and is one of the financial institutions that conducts business based on sharia principles. Islamic banking as a banking system that is relatively new when compared to the existence of conventional banking that has been established. It consists of Islamic commercial banks, Islamic business units, and Islamic people's credit banks. According to Rachmadi Usman, one aspect that distinguishes between Islamic banking and conventional banking is in its supervision, where there are more supervisory institutions in Islamic banking than conventional banking. [20]

The following are the institutions/institutions that play a role in the development of Islamic banking in Indonesia: 1) The Financial Services Authority which has the domain of regulators and supervisors; 2) Bank Indonesia in the realm of monetary policy, prudential macro supervision, payment systems for the banking sector; 3) the Deposit Insurance Agency in the area of savings insurance; 4) National Sharia Council - Indonesian Ulema Council in the realm of fatwas, sharia guidelines, sharia opinions; 5) The Ministry of Finance has the domain of sukuk and state bonds issuance; 6) The Ministry of Cooperatives and Small and Medium Enterprises has the realm of regulators and supervision of Islamic cooperatives; 7) Ministry of Religion in the realm of Hajj fund management, zakat regulator and waqf regulator; 8) Sharia Supervisory Board as sharia advisors; 9) The Indonesian Institute of Accountants has the domain of accounting standards for Islamic financial instruments, and; 10) National Sharia Arbitration Board which is a special court for sharia arbitration for financial matters. [12]

Various strategies have been designed by the Indonesian government in accelerating the growth of the sharia financial industry in the country so that it has a great impact on national development. These strategies hopefully will be a blueprint for the development of sharia banking of Bank Indonesia and also the Roadmap for the development of sharia banking in Indonesia which has been made by the Financial Services Authority. In terms of strategies for developing sharia banking and its products, Indonesia has chosen a gradual and sustainable approach that complies with sharia principles and does not adopt controversial contracts. [21] A gradual and continuous approach enables development according to the circumstances and readiness of the perpetrators without being forced and forms a robust and not fragile system. [21] Sharia banking in general is growing did not meet the expected target yet due to the lack of a shared national vision, lack of coordination between regulators and other institutions, and the lack of national leadership to unite the strategic steps of each stakeholder.[12]

From the above analysis, we can draw the conclusion that in the development of Islamic banking there are several institutions involved in the development of Islamic banking in Indonesia, but the absence of good cooperation causes the growth of Islamic banking to be not optimal.

\subsection{The Role of the National Sharia Finance Committee in the Development of Sharia Banking Law in Indonesia}


From the discussion, it was found that there was a reason for not achieving the targets of the development of sharia banking. In this analysis, it would analyze the role of the National Sharia Finance Committee in the development of sharia banking law in Indonesia.

As a manifestation of the government's commitment to developing Islamic finance with the enactment of Presidential Regulation Number 91 of 2016 concerning the National Sharia Finance Committee. [22] The establishment of the National Sharia Finance Committee is expected to awaken the potential of the sharia economy in Indonesia and make Indonesia the leading center of sharia economics and finance in the world. According to the definitions in the general provisions of Article 1 paragraph (1) of Presidential Regulation Number 91 of 2016 concerning the National Sharia Finance Committee, the National Sharia Finance Committee is a forum for coordination, synchronization and synergy in the direction of national development policies and strategic programs in the sharia financial sector. Furthermore, this institution has the task of accelerating, expanding, and advancing the development of Islamic finance in order to support national economic development in accordance with what is contained in Article 3 of Presidential Regulation Number 91 of 2016 concerning the National Sharia Finance Committee.

Before the existence of the National Sharia Finance Committee, the stakeholders in the sharia banking industry in the country seemed to work alone in carrying out their duties so that the results were less effective. There was no shared vision in developing national sharia banking. It is hoped that after the establishment of the National Sharia Finance Committee all stakeholders in the national sharia banking industry can establish very good cooperation so that the acceleration of the development of the national sharia banking can run in accordance with the targets set so that the large contribution to national development will increase rapidly. In accordance with the slogan owned by the National Sharia Finance Committee, this committee has the role of uniting the steps of the stakeholders in the Islamic banking industry. [23] The unification of steps undertaken by the National Sharia Finance Committee is likened to the leader of a group of rowing athletes, the cohesiveness of each rowing by the rowers can make the rowing more effective and efficient when compared to each rower rowing - alone without the presence of someone giving the command to guide the compactness team.

In carrying out this role the National Sharia Finance Committee has been explained in Article 4 letter (a) through letter (d) of Presidential Regulation Number 91 of 2016 that this Committee carries out functions which include: (a) providing recommendations on policy directions and national development strategic programs in the Islamic financial sector; (b) organizing the preparation and implementation of planned strategic policy directions and programs in the Islamic financial sector; (c) formulating and giving recommendations for solving problems in the Islamic financial sector; (d) monitoring and evaluation of the implementation of strategic policies and programs in the Islamic financial sector. In carrying out this function the Steering Board is assisted by Executive Management, as explained in Article 11 of Presidential Regulation No. 91 of 2016 that Executive Management is tasked with implementing the direction of national strategic policies and programs as well as sharia financial activities formulated by the Steering Board.

In carrying out its duties the Executive Management is led by the Executive Director, as stipulated in Article 5 of the Minister of National Development Planning Regulation/Head of the National Development Planning Agency of the Republic of Indonesia Number 13 of 2017 concerning the Organizational Structure and Working Procedures of the Executive Management of the National Sharia Finance Committee, it has been explained that the Executive Director has some roles including: 
a. Organizing the preparation, formulation, and recommendations on policy directions and national development strategic programs in the Islamic financial sector;

b. Organizing the preparation and implementation of national development strategic program plans in the Islamic financial sector and the Master Plan of Action;

c. Organizing the management and processing of data and information regarding the development of national development in the Islamic financial sector;

d. Organizing the preparation of a business process map that illustrates the effective and efficient institutional working relations of the Sharia National Committee between ministries/agencies, authorities, and other stakeholders;

e. Organizing the relationship for national development with the central government, regional governments, authorities, development partners, and private parties in the country and abroad;

f. Organizing domestic and foreign investment raising for national development in the Islamic financial sector;

g. monitoring and evaluating of the formulation and implementation of policies and national development strategic programs in the Islamic financial sector;

h. Organizing socialization, advocacy, promotion and education on Islamic economic and financial activities;

i. Organizing the implementation of the secretarial function of the National Committee of Islamic Finance;

j. Performing other tasks and functions given by the Steering Committee of the National Sharia Finance Committee; and

k. Preparation of reports on the implementation of duties to the Steering Committee of the Sharia National Committee through the Minister who organizes government affairs in the field of national development planning as the Secretary of the Steering Board of the Sharia National Committee every 6 (six) months or at any time if necessary.

In order to get the duties and functions done on the Executive Director level, it has has been mandated to form an ad hoc task force and is determined by the Minister of National Development Planning as Secretary of the Steering Committee of the National Sharia Finance Committee. This has been explained in Article 6 of the Regulation of the Minister of National Development Planning/Head of the National Development Agency No. 13 of 2017 concerning the Organizational Structure and Work Procedures of the Executive Management of the National Sharia Finance Committee. The Work Unit/task force formed consists of:

a. Directorate of Legal Affairs and Sharia Financial Management Standards;

b. Directorate of Product Innovation, Market Deepening and Sharia Financial System Infrastructure Development;

c. Directorate of Inclusive Finance, Religious Social Funds, and Sharia Micro Finance.

d. Directorate of Sharia Finance Education and Research, and;

e. Directorate of Promotion and External Relations.

It can seen that the directorate in the field of law and sharia financial management standards is a directing authority possessed by the Financial Services Authority and the National Sharia Council - Indonesian Ulema Council. National Sharia Council - Indonesian Ulema Council is the highest independent institution in terms of sharia governance. In the Islamic banking sector which has the authority to issue regulations is the Financial Services Authority. One of the recommendations in the legal sector is to improve the regulatory 
framework. [12] Although the number of regulations that have been made has been able to help create legal certainty in the Islamic banking sector, but it also causes confusion for market participants and consumers because of many regulations and overlapping.

According to Adiwarman, most of the Bank Indonesia Regulations and Financial Services Authority Regulations need to be consolidated, for example, the codification of the sharia banking rule book is made online, so that the rules regarding sharia banking can be better understood so that it will help the interested parties. [24] With the existence of the National Sharia Finance Committee can assist the Financial Services Authority in making the regulations needed in strengthening Islamic banking regulations. According to Widiyono, the increase in tasks at the Financial Services Authority did not significantly influence the timeliness in completing the work program that has been set. if there is an additional work to complete the program, it will not delay the current jobs that much.. [25] Widiyono further stated that the recommendation of the National Sharia Finance Committee which led to an increase in work programs would not interfere with the performance of the Financial Services Authority. [25] That is because the Financial Services Authority has a separate Pokja team to handle it. [25] Until now there has been no work program given from the recommendations of the National Islamic Finance Committee to the Financial Services Authority. [25] In carrying out the task of formulating the direction of national strategic policies and programs as well as activities in the sharia financial sector in the field of law and sharia management standards, the directorate of law and sharia management standards is led by the director of the field.

\section{Conclusion}

The National Sharia Finance Committee in developing sharia banking law in Indonesia has the role of becoming an independent supervisory body that monitors the application of the Road Map for the development of sharia banking and ensures that all stakeholders meet the requirements of the master plan. 


\section{References}

[1] G. Dewi, Aspek - aspek Hukum dalam Perbankan dan Perasuransian Syariah di Indonesia. Jakarta: Kencana, 2006.

[2] M. Sinungan, Uang dan Bank. Jakarta: Bina Aksara, 1987.

[3] Detik Finance, "Ketimpangan Ekonomi Bukti Kegagalan Sistem Kapitalisme,” 12 Jul 2008. [Online]. Available: https://finance.detik.com/berita-ekonomi-bisnis/d970933/ketimpangan-ekonomi-bukti-kegagalan-sistem-kapitalisme.

[4] A. M. Syaifudin, Ekonomi dan Masyarakat dalam Perspektif Islam. Jakarta: Rajawali Pers, 1987.

[5] H. Alamsyah, The speech of the Deputy Governor of Bank Indonesia delivered at the end of the annual seminar on the outlook for sharia banking in 2011. 2010.

[6] K. Syafei, A. W., Widuhung, S. D., \& Hadi, "Penerapan Teknologi (Sistem) Berbasis Islam Pada Bank Syariah di Indonesia,” J. Al-Azhar Indones. Seri Pranata Sos., vol. 2, no. 1, pp. 1-11, 2013.

[7] A. Novia, "Kontribusi Fiqh Legal Maxim dalam Fatwa-Fatwa Ekonomi Syariah Dewan Syariah Nasional Majelis Ulama Indonesia (DSN-MUI)," Tsaqafah, vol. 12, no. 1, pp. 79-104, 2016.

[8] K. Umam, "Peningkatan Ketaatan Syariah Melalui Pemisahan (Spin-off) Unit Usaha Syariah Bank Umum Konvensional," Mimb. Hukum-Fakultas Huk. Univ. Gadjah Mada, vol. 22, no. 3, pp. 607-624, 2010.

[9] R. F. Setyowati, "Perlindungan Khusus Bagi Nasabah Perbankan Syariah dalam Perspektif Perlindungan Konsumen,” Masal. Huk., vol. 39, no. 3, pp. 205-212, 2010.

[10] Departemen Perizinan dan Informasi Perbankan Otoritas Jasa Keuangan (OJK), "Statistik Perbankan Syariah - Agustus 2019." [Online]. Available: https://www.ojk.go.id/id/kanal/syariah/data-dan-statistik/statistik-perbankansyariah/Documents/Pages/Statistik-Perbankan-Syariah---Agustus-2019/SPS Agustus 2019.pdf.

[11] M. S. A. Majid, "Regulasi Perbankan Syariah: Studi Komparatif Antara Malaysia Dan Indonesia,” Media Syari'ah, vol. 16, no. 1, pp. 231-254, 2017.

[12] Kementerian Perencanaan Pembangunan Nasional/Bappenas, Masterplan Arsitektur Keuangan Syariah Indonesia. Jakarta: Bappenas, 2016.

[13] B. Vizcaino, "Malaysia PM backs idea of creating Islamic mega bank," 29 Oct 2014. [Online]. Available: https://www.reuters.com/article/malaysia-islam-bankingprimeminister/malaysia-pm-backs-idea-of-creating-islamic-mega-bankidUSL5N0SN3P720141028.

[14] H. H. Nawawi, Penelitian Terapan. Yogyakarta: Gadjah Mada University, 1996.

[15] S. Soekanto, Pengantar Penelitian Hukum. Jakarta: UI Press, 1986.

[16] R. H. Soemitro, Metodologi Penelitian Hukum dan Jumiteri. Jakarta: Ghalia Indonesia, 1994. 
[17] S. Arikunto, Prosedur Penelitian Suatu Pendekatan Praktek. Jakarta: Rineka Cipta, 2002.

[18] A. Muhammad, Hukum dan Penelitian Hukum. Bandung: Citra Aditya Bakti, 2004.

[19] B. Waluyo, Penelitian Hukum Dalam Praktek. Jakarta: Sinar Grafika, 2002.

[20] R. Usman, Aspek - aspek Hukum Perbankan Syariah di Indonesia. Jakarta: Sinar Grafika, 2012.

[21] Ascarya, Comparing Islamic Banking Development in Malaysia and Indonesia: Lessons for Instruments Development. Jakarta: Bank Indonesia.

[22] Presidential Regulation Number 91 of 2016 concerning National Sharia Finance Committee. .

[23] Komite Nasional Ekonomi dan Keuangan Syariah (KNEKS), “Tentang KNEKS," 2019. [Online]. Available: https://knks.go.id/tentang.

[24] Kementerian Keuangan Republik Indonesia, "Berkah Ekonomi Syariah," Media Keuangan, 2019.

[25] Interview with Widiyono, Sub Division of Information and Documentation, Financial Services Authority Regional Office 3 Central Java and Yogyakarta Special Region, 19 June 2019, in Semarang. . 